\title{
Ordem jurídica, religião, direitos civis e a constituição do Império do Brasil
}

João Marcos Leitão dos Santos*

\section{RESUMO}

Neste trabalho procuramos discutir as relações entre religião e ordem legal, sobretudo, com vistas a mapear as condiçóes para a construção da proteçâo jurisdicional oferecida pelo Estado Imperial ante o crescimento de populaçôes acatólicas no Brasil. Sob a égide das diversas ideologias liberais que se apresentavam no país, acompanhamos a consolidaçáo de uma ordem jurídica emanada dos debates parlamentares, que deram as feiçóes ao exercício da cidadania no império.

Palavras-chave: direitos civis; Constituição; populações acatólicas; Brasil Império; religião.

\section{ABSTRACT}

In this paper we seek to discuss the relationship between religion and legal order, with the particular goal of mapping the conditions for the creation of the jurisdictional protection offered by the Imperial State, in view of the growth of Acatholic populations in Brazil. Under the aegis of the various liberal ideologies that were present in the country, we witnessed the consolidation of a legal order emanating from the parliamentary debates that informed the exercise of citizenship in the Brazilian Empire.

Keywords: civil rights; Constitution; Acatholic populations; Brazilian Empire; religion.

\section{RESUMEN}

En este trabajo pretendemos discutir las relaciones entre religión y orden legal, sobre todo con vistas a mapear las condiciones para la construcción de la protección jurisdiccional ofrecida por el Estado Imperial ante el crecimiento de poblaciones acatólicas en Brasil. Bajo la égida de las diversas ideologías liberales que se presentaban en el país, acompañamos la consolidación de un orden jurídico emanado de los debates parlamentares, que conformaron al ejercicio de la ciudadanía en el Imperio.

Palabras clave: derechos civiles; Constitución; poblaciones acatólicas; Brasil Imperio; religión.

DOI: http://dx.doi.org/10.1590/2237-101X01903701

Artigo recebido em 5 de junho de 2015 e aprovado para a publicação em 10 de setembro de 2017.

* Professor da Universidade Federal de Campina Grande. E-mail: tmejph@bol.com.br.

Parte resultante do projeto Religião, Jurisdicionalidade e Cidadania. Direitos Civis e Dissidência Religiosa no Império, com apoio financeiro do CNPq. 
Não é equivocado afirmar que a construção da ordem jurídica no império refletiu os embates entre as ideias renovadoras de origem liberal e a oposiçấo a elas. Como uma das mais importantes propostas doutrinárias do período moderno, o liberalismo contido, pauta ordenadora da ordem social imperial, em sua configuração esteve associado à ideia de mudança, como fórmula alternativa de superação do colonialismo. Ao perseguir as bases ideológicas para a travessia da condição colonial no país, o liberalismo se erigiu como nova matiz para a organizaçáo social. Do ponto de vista ético-filosófico, implicava afirmar valores ligados à condição natural e moral dos sujeitos, cujas expressóes mais evidentes eram individualismo, tolerância, dignidade da pessoa e valor da vida, e do ponto de vista político e jurídico, princípios do consentimento individual, representação política, divisão dos poderes, soberania popular, supremacia constitucional e garantias individuais, agregados todos estes no Estado de Direito pretendido. ${ }^{1}$

Neste trabalho pretendemos apresentar faces jus-políticas da configuração do Estado imperial na acomodação das tendências em disputa, debatidas no parlamento, evidenciando o pensamento religioso católico marcante no país, ante o desafio das recém-constituídas comunidades acatólicas advindas das missóes protestantes, analisando o provimento de bases legais para essas populaçóes.

\section{Liberalismo e ordem legal}

Conceito polissêmico, quiçá polissemiótico, cujo grafema, e cujo sentido, nunca guardou nem pretendeu significação e práticas herméticas, o liberalismo brasileiro ${ }^{2}$ se distinguiu do modelo europeu, entre outras razóes, porque instrumentalizado para oferecer suporte às elites oligárquicas, traduzindo-se pelo imperativo de reordenação do poder nacional independente, preservando, contudo, certa gradação na dominação das elites agrárias e tendo como principal limitação a "peculiar convivência com a institucionalização do escravismo". ${ }^{3}$

Ao referir às ressonâncias sociais do liberalismo, Lara afirma que "sob certo ponto de vista, chocava-se com características fundamentais da sociedade brasileira", pois "não era um discurso desencarnado e exigia a manifestação na organização política e econômica", ${ }^{4}$ indicando

\footnotetext{
${ }^{1}$ PAIM, Antonio. História das ideias filosóficas no Brasil. São Paulo; Brasília: Convívio; INL, 1984.

${ }^{2}$ Este texto, embora reconheça o significado da discussão sobre o liberalismo, não se propóe a realizar uma revisão da bibliografia sobre o tema, sobretudo aquela considerada clássica, restringindo-se às indicaçóes no texto das tendências mais recorrentes, quando implicadas. Interessado, ver principalmente: PIÑEIRO, Théo Lobarinhas. Os projetos liberais no Brasil império. Passagens. Revista Internacional de História Política e Cultura Jurídica, Rio de Janeiro, v. 2, n. 4, p. 130-152, maio/ago. 2010; PEIXOTO, Antonio Carlos et. al. Liberalismo no Brasil imperial. Origens, conceitos e prática. 2. ed. Rio de Janeiro: Revan, 2013.

${ }^{3}$ WOLKMER, Antonio Carlos. História do direito no Brasil. Rio de Janeiro: Forense, 1998, p. 76.

${ }^{4}$ LARA, Tiago Adão. Tradicionalismo católico em Pernambuco. Recife: Fundarpe, 1988, p. 11.
} 
a capilaridade das recepçóes do liberalismo no Brasil. Tais forças em choque estão expostas por Mercadante 5 quando nos mostra nos debates e nos modelos de reorganização das relações internas e externas de produção que respondesse ao fim da ordem colonial manifestas cisóes. Nesse processo, como aponta nossa historiografia, a formação do Estado apresentou diferentes leituras do liberalismo, conformadas aos interesses em disputa com teses em torno de um pensamento conservador prevalecente cujo ápice seria a Conciliação, ${ }^{6}$ ou de um conflito estrutural, em que conservadores buscavam a construção de monopólios para a continuidade da lógica colonial, ${ }^{7}$ ou "originalidade" do movimento político no Brasil, aprendendo-o como uma figura híbrida, no qual o conservadorismo representa a contraface das práticas liberais. ${ }^{8}$

A tarefa de fundamentar a independência no plano jus-político e sociocultural implicava a recomposição das estruturas de poder e suas bases jurídicas, demandando a qualificação de um novo segmento para a operação do sistema burocrático-administrativo, recolhido, em um primeiro momento, nos egressos de Coimbra, e, na sequência, nos bacharéis de São Paulo e Recife. O paradoxo desse processo indica a disparidade entre propugnar pelos princípios ecléticos do nosso liberalismo e fomentar os instrumentos de controle do poder por aquela elite burocrática, herdeira da ideologia oligárquica e colonial coimbrã.

Na problemática afeita a esse trabalho o cenário revela que a normatização das matérias religiosas na Constituição9 refletia remotamente os termos do Tratado de 1810, em relação aos acatólicos, que fixava liberdade para a prática religiosa, sua conformidade aos limites da legislação vigente e a ordem pública e a restrição ao proselitismo. A Constituição de 1823 foi proposta sob influxo liberalismo constitucionalista francês, esforçando-se pela acomodação conciliatória da estrutura patrimonial do Estado e um modelo de prática política para o exercício do poder calcado no liberalismo, tipicamente exemplificado no assegurar de direitos, cuja efetividade era passível de supressão. Diz Wolkmer:

No contexto inicial da colonização e da exploração das riquezas, não houve lugar para qualquer elaboração de ideias originais, pois toda e qualquer produção teórica ficou reduzida à propagação missionária (...) [imposta] pelos jesuítas. No mimetismo sacralizado (...) não comporta registrar uma teoria jurídica secularizada, pois toda a concepção sobre a lei, direito e justiça, restringiase "às diretrizes ético-religiosas da Igreja católica", que refletia um jusnaturalismo tomistaeclesiástico. ${ }^{10}$

\footnotetext{
${ }^{5}$ MERCADANTE, Paulo. A consciência conservadora no Brasil. Rio de Janeiro: Saga, 1965.

${ }^{6}$ CARVALHO, José Murilo de. A construção da ordem: a elite política imperial. Rio de Janeiro: Campus, 1980.

${ }^{7}$ MATTOS, Ilmar Rohloff de. O tempo Saquarema. São Paulo: Hucitec; Brasília: INL, 1987.

${ }^{8}$ COSTA, Emília Viotti da. Da monarquia à república: momentos decisivos. São Paulo: Brasiliense, 1987.

${ }^{9}$ CIARALO, Gilson. O tema da liberdade religiosa na política brasileira do século XIX: uma via para a compreensão da secularização da esfera política. Revista de Sociologia e Política, Curitiba, v. 19, n. 38, p. 85100, fev. 2011. CHAVANTE, Esdras Cordeiro. Tavares Bastos e a construção da liberdade religiosa. Revista Brasileira de História das Religióes, Maringá, v. V, n. 15, p. 1-12, jan. 2013.
}

${ }^{10}$ WOLKMER, Antonio Carlos. História do direito no Brasil, op. cit., p. 125. 
Souza completa:

Herdeiros da cultura política difundida pelo reformismo ilustrado português, os membros da Constituinte de 1823 não puderem abrir máo do elemento religioso, no momento de elaborar, com base no pensamento político moderno, o arcabouço político-jurídico para o Estado brasileiro. ${ }^{11}$

A questáo que ocupou o parlamento era conciliar o pensamento religioso e o pensamento político moderno, secular e laicista por princípio, no contexto que envolvia catolicismo, liberalismo, protestantismo e direitos civis. Ícone do liberalismo "radical", isto é, republicano, avisava Silva Jardim: "A liberdade que ele tem não está garantida na lei: as leis mandam castigar tudo que for contra a monarquia, contra Religiáo, Contra o Imperador etc.", concluindo: "Não temos liberdade de religião: a lei nos obriga todos os brasileiros a serem católicos; e por isso os estrangeiros protestantes etc., não podem viver bem no Brasil."12

A tese é meridiana, ser brasileiro e católico era experiência indivisível, quando menos por coação legal, pois "a lei obriga". Essa tese também está em Azzi, ${ }^{13}$ que ser português e católico era fato indistinto, e que se estende ao Brasil independente nos termos da lei de 20 de outubro de 1823:

D. Pedro I, por Graça de Deus...

A Assembléa Geral Constituinte e Legislativa do Imperio do Brazil Decreta.

Art. 1ํㅡㄹ As Ordenaçóes, Leis, Regimentos, Alvarás, Decretos, e Resoluçōes promulgadas pelos Reis de Portugal, e pelas quaes o Brazil se governava até o dia 25 de Abril de 1821, em que Sua Magestade Fidelissima, actual Rei de Portugal, e Algarves, se ausentou desta Côrte; e todas as que foram promulgadas daquella data em diante pelo Senhor D. Pedro de Alcantara, como Regente do Brazil, em quanto Reino, e como Imperador Constitucional delle, desde que se erigiu em Imperio, ficam em inteiro vigor na pare (sic), em que não tiverem sido revogadas, para por ellas se regularem os negocios do interior deste Imperio, emquanto se não organizar um novo Codigo, ou não forem especialmente alteradas.

Paço da Assembléa em 27 de Setembro de $1823^{14}$

Mas este estado de coisas estaria em mudança no Dezenove com a quebra da unidade religiosa resultante do advento protestante. A primeira explicação vem de Veiga:

\footnotetext{
${ }^{11}$ SOUZA, François Oliveira. Liberdade religiosa em um estado religioso: liberalismo e catolicismo nos debates da Assembleia Constituinte de 1823. Temporalidades, Belo Horizonte, v. 4, p. 229-249, ago./dez. 2012. p. 237. ${ }^{12}$ JARDIM, Antonio da Silva. Propaganda republicana (1888-1889). Rio de Janeiro: Casa de Rui Barbosa, 1978, p. 184.

${ }^{13}$ AZZI, Riolando. A cristandade colonial: um projeto autoritário. Petrópolis: Vozes, 1987.

14 Disponível em: <http://www2.camara.leg.br/legin/fed/lei_sn/anterioresa1824/lei-40951-20-outubro-1823574564-publicacaooriginal-97677-pe.html>.
} 
É essa dinâmica frequentemente disfarçada sob a denominação de progresso que, em acelerando as relaçóes sociais, estabelece o divórcio e a oposição entre a cidade e o campo, desprestigiando este progresso - a palavra e a ideologia — que náo foi legado do positivismo, porém do protestantismo, quando a partir dos anos 30 começou a minar a ortodoxia e depois o ultramontanismo.

Depois de 1850 irromperiam os protestantes como agentes do "progresso", acelerando o rompimento total como século XIX. E com os protestantes - americanos e ingleses — toda a tecnologia moderna. ${ }^{15}$

$\mathrm{Na}$ vinda do protestantismo "temia-se no adventício acatólico o inimigo político...", diz Freire, ${ }^{16}$ e o liberalismo que lhe era associado. Amoroso Lima explica:

as relaçóes entre Igreja e Estado no Brasil, longe de haverem constituído segundo a doutrina católica, se instauraram na base da heresia galicana e pombalina, que derivada do jansenismo, constitui forma de protestantismo (...) o liberalismo é um desvio do protestantismo. ${ }^{17}$

Estas são as faces que ganham o temor ou a expectativa relativas à inserção do protestantismo, que Veiga exemplifica em Braz Florentino e do Tradicionalismo Católico:

(...) assombravam-se Braz Florentino e demais ortodoxos, não pela maré montante da colonização estrangeira (...) angustiavam-se pois, à retaguarda da maré de imigrantes, erguia-se o vagalhão assustador do protestantismo, significando, realmente o livre exame e a liberdade de consciência. ${ }^{18}$

Portanto, os brasileiros estavam "naturalmente" sobre a proteção da lei, mas como e até onde acomodar este novo adventício e oferecer-lhe proteção jurisdicional? É sobre essas questôes que se debruça o parlamento, conforme aqui discutido.

\section{A ordem jurídica do império: religião e direitos civis}

A Constituição efetivada (1824) estabelecia com clareza no art. 5o o status da religião: "A religião Católica Apostólica Romana continuará a ser a do Império. Todas as outras serão permitidas com seu culto doméstico ou particular, em casas para isto destinadas, sem forma exterior de templo.” Porém, essas formulações não foram concordes.

${ }^{15}$ VEIGA, Gláucio. História das ideias da Faculdade de Direito do Recife. Recife: Edufpe, 1984/1990. t. IV/ VII, p. 127, 151 (grifo nosso).

${ }^{16}$ FREIRE, Gilberto. Casa grande e senzala. São Paulo: Círculo do Livro, 1990, p. 66.

${ }^{17}$ LIMA, Alceu Amoroso. Política. São Paulo: Herder, 1935, p. 115 (grifo nosso).

${ }^{18}$ VEIGA, Gláucio. História das ideias da Faculdade de Direito do Recife, op. cit., t. VII/VII, p. 197 (grifo nosso). 
No projeto da constituinte, o visconde de Cairu e Muniz Tavares se digladiaram em torno da ampliação ou restrição de direitos à liberdade religiosa e ao pensamento, e paradoxalmente, era o monsenhor Muniz Tavares quem apresentava um discurso "progressista", entendendo dever do Estado proteger seus súditos, qualquer que fosse sua "opção" religiosa, não lhes impedindo o culto. Argumentava: "se a um brasileiro naturalizado se fazia concessóes, não se haveria de negá-las ao brasileiro nato”, em tese, portador de maiores direitos.

Silva Lisboa sofismava contrapropondo distinguir liberdade de culto e religiosa sugerindo que cada um "pensaria religiáo" conforme sua opção, mas "a concessão da faculdade ilimitada aos naturais do país de professarem seitas de países estrangeiros...” era nociva, pois "liberdade religiosa, considerando as circunstâncias do Brasil, vem a ser liberdade de perjúrio e liberdade de apostasia", ${ }^{19}$ náo se constituindo demanda da sociedade. O projeto discutido era bem mais abrangente do que o texto promulgado. No art. 5o, inicialmente, previa o projeto:

Art. 14 - Cada membro das confissóes cristãs pode professar a sua religião no recinto destinado para este fim. Todos os que professarem estas comunhóes podem gozar dos direitos políticos. Art. 15 - As outras religióes além da cristã são apenas toleradas e só lhes compete o culto doméstico.

Art. 16 - A religião Católica Apostólica Romana é a religião do Estado, e a única mantida por ele, e só a ela compete o culto externo fora das igrejas.

Art. 26 - São cidadãos brasileiros (...)

$\$ 5^{\circ}$ - Os estrangeiros naturalizados, qualquer que seja a sua religião.

Estabelecido o art. 5ํㅗ também o art. 179 instituía:

$\$ 4^{0}$ - Todos podem comunicar seus pensamentos por palavras, escritos e publicá-los pela imprensa, sem dependência de censura, contanto que hajam de responder pelos abusos que cometerem no exercício desses direitos, nos casos e na forma que a lei determinar.

$\$$ 5을 Ninguém pode ser perseguido por motivo de Religião uma vez que respeite a do Estado, e não ofenda a moral pública.

$\$ 14^{\circ}$ - Todo cidadão pode ser admitido aos órgãos públicos civis políticos e militares, sem outra diferença que não seja a de seus talentos e virtudes.

Outra legislação pertinente se encontrava no Código Criminal (1830). O Código era necessidade reconhecida desde a Constituiçáo de 1824: "Organizar-se-á quanto antes um Código Civil, e Criminal, fundado nas sólidas bases da Justiça e da Equidade”; e visava subs-

\footnotetext{
${ }^{19}$ LISBOA, Silva apud RIBEIRO, Boanerges. Protestantismo no Brasil monárquico. 1822-1888. São Paulo: Perspectiva, 1973, p. 28.
} 
tituir o Livro $\mathrm{V}$ das Ordenaçôes. Mas já a partir da sua vigência “(...) abusos verificados em certas Províncias, com leis provinciais inconstitucionais, justificariam a Lei de Interpretação".

(...) o Código precisava de algumas reformas, assim na parte em que, não tendo criado autoridades policiais, confiara as funções policiais aos juízes de paz, municipais e de direito (chefe de polícia nas capitais), o que era inadmissível, mistura perigosa de poderes, que vieram a ser reprimidos pela Lei de 3 de dezembro de 1841, [e] seu regulamento 120, de 31 de janeiro de $1842 .^{20}$

O Código Criminal trazia certa proteção aos acatólicos definindo em que consistia o "desrespeito à religiáo do Império": "Obras ou doutrinas que destruíssem as verdades fundamentais da existência de Deus e da imortalidade da Alma", art. 278, e prisão de "um a três meses", "além das mais que possa incorrer" para quem "perseguir por motivo de religião ao que respeita a do Estado e não ofende a moral pública”, art. 191. ${ }^{21}$

É evidente a destinação dessa legislação: os acatólicos, uma vez que é óbvio que aos católicos em um país que tinha esse credo como religião oficial e herança cultural não havia questóes quanto aos seus direitos civis, como demonstramos.

A imigração era apenas uma das diversas conjunturas na dinâmica da vida imperial, que como a expressáo sugere, muitas questóes eram conjunturais, mas a imigração tinha um status destacado e constituía-se em uma dimensão estrutural, ${ }^{22}$ como outras aqui referidas, como a Questão Religiosa.

Tal problema da imigração já fora colocado pelo senador Souza Brasil, padre, jurista formado em Olinda, elencando, entre os obstáculos para o desenvolvimento da agricultura, o problema religioso, uma vez que "os protestantes aqui não podiam constituir família legítima segundo as nossas leis". ${ }^{23}$

Todavia não havia que se esperar muito do texto constitucional. Se por um lado a Carta era consentânea com o espírito da época, sua aplicação era problemática, como apontam os debates parlamentares. No dizer de Barroso, "Os desajustes se têm revelado, de forma

\footnotetext{
${ }^{20}$ VALLADÃO, Haroldo. História do direito principalmente brasileiro. Imperial e republicano. Rio de Janeiro: Freitas Bastos, 1973, p. 130 2V.

${ }^{21}$ Arriscado reificar o problema de forma simplista: "Assim, ainda que de forma preliminar, já se pode informar que alguns autores defendem que de fato não existia liberdade religiosa durante o Império brasileiro", tomando liberdade religiosa como sinônimo das prerrogativas da Igreja. Igualmente impreciso no tratamento da liberdade religiosa é a afirmação de que "os positivistas defendiam uma inteira liberdade à Igreja católica e às demais religiōes existentes no país" (OLIVEIRA, Bruno. Liberdade religiosa no Brasil império e no Brasil contemporâneo. Revista Eletrônica do Curso de Mestrado em Direito da UFAL, op. cit.

${ }^{22}$ Exemplo dessa questáo foi a recusa pelo governo imperial em rejeitar a proposta do coronel T. Hawtorne de fundar uma colônia em São Paulo com 100 mil imigrantes norte-americanos. À época, considerou o governo inadequado concentrar 100 mil estrangeiros em um mesmo espaço territorial, ao passo que Hawtorne recusava a distribuição do grupo em contingentes menores nas diversas províncias do império.

${ }^{23}$ AS. Anais da Assembleia Geral Legislativa do Império do Brasil. 1823. Brasília: Senado Federal, 1999, v. I, p. 259ss.
} 
drástica e insuperável, na realização do desiderato constitucional". ${ }^{44} \mathrm{Ou}$ seja, a Constituição não guardava perfeita simetria com a organização social, e não estava apta a garantir os direitos que propugnava..$^{25}$ Exemplo claro está no art. 179, inciso xiii: "A Lei será igual para todos, quer proteja, quer castigue, e recompensará em proporção dos merecimentos de cada um", ao mesmo tempo que diferenciava entre os membros da sociedade. Faoro referia a uma "Constituição puramente nominal, incapaz de disciplinar, coordenar, imperar, ideal teórico de uma realidade estranha à doutrina e rebelde à ideologia política”. ${ }^{26}$

Deste quadro, os embates parlamentares parecem bom indicador, sobretudo, se consideramos que a "ordem jurídica" não podia emanar de outra fonte exceto o parlamento, senão eventualmente, do arbítrio do imperante, e o duelo entre projetos de sociedade tem responso na legislação. Por conta disso, a Constituição, embora cumprisse papel fundamental, não era garantia suficiente aos setores minoritários e muito menos da pluralidade do social.

\section{Uma face paradigmática da lei: casamento acatólico}

Em 1857, d. Pedro Lacerda mandou anular a união do casal alemão e protestante Johann Schoop e Margarethe Kerth, fato que se repetiu com outra família na década de 1870, por iniciativa de um vigário no Espírito Santo, com dois agravantes: admitiu às duas nubentes contraírem novas núpcias após a sua abjuração do protestantismo, e era ilegal, uma vez que em 1870 já estava em vigência a Lei no 1.144/1861, regulado no Decreto nº 3.009/1863, que permitia aos ministros protestantes cadastrados a celebraçáo de casamentos com efeitos civis.

A legação imperial alemã representou ao governo solicitando a regulamentação dos casamentos das colônias germânicas, e a matéria subiu para a apreciação do Conselho de Estado, com aceite do imperador, mandando desfazer a medida do vigário e ameaçando enquadrar as nubentes no Código Criminal. ${ }^{27}$

O parlamento em quatro ocasióes debruçou-se sobre as propostas de regulamentação do casamento imigrante: no projeto do senador Vergueiro, em 1829; depois de Feijó, em 1833; e com duas propostas do governo imperial, em 1858 e 1859, até a forma final em 1863.

Os projetos primeiros só referiam à situação em que um dos nubentes guardasse religiáo díspare em relação ao consorte, os chamados casamentos mistos, e exigia, além do registro da igreja junto ao governo, que o rito fosse precedido dos proclamas e celebrado por ministro registrado junto ao Estado, com lavratura na Câmara Municipal mais próxima.

\footnotetext{
${ }^{24}$ BARROSO, Luis Roberto. O Direito Constitucional e a efetividade de suas normas: limites e possibilidades da Constituição brasileira. Rio de Janeiro: Renovar, 1990, p. 6.

${ }^{25}$ VEIGA, Gláucio. História das ideias da Faculdade de Direito do Recife, op. cit., t. IV.

${ }^{26}$ FAORO, Raymundo. Os donos do poder. Porto Alegre: Globo, 1979, p. 291. 2v.

${ }^{27}$ A reação dos imigrantes e de seus representantes junto ao governo imperial não se esgotou nessa iniciativa, e solicitaram, em setembro de 1887, a revogação do art. 5ำ da Constituição.
} 
As primeiras tentativas para a acomodação do matrimônio foram iniciativas do missionário escocês Robert R. Kalley, pioneiro das missóes protestantes na segunda metade do século XIX. Kalley não tinha prioritariamente interesse em provocar mudanças nas práticas sociais do império, senão como consequência; sua expectativa principal era remover entraves para adesão de novos fiéis ao protestantismo. ${ }^{28} \mathrm{O}$ primeiro esforço de regulamentação foi um contrato entre os nubentes, ao qual se pretendia atribuir o valor ético mais do que propriamente civil ou legal.

Nós, abaixo assinados, sabendo que o casamento é uma instituição divina e não podendo casar-nos conforme o rito romano, único que a lei do Brasil reconhece, pois nós cremos que o romanismo opóe-se às leis de Deus, temos prometido e por este documento declaramos e confirmamos a promessa de cumprir entre nós os deveres de marido e mulher, conforme a Palavra de Deus nas Escrituras Sagradas.

Eu, (nome do homem, profissão ou estado, naturalidade, filiação e respectiva naturalidade), recebo por minha única legítima mulher a (nome da mulher, profissão ou estado, idade, naturalidade, filiação e respectiva naturalidade, legitimidade), e me obrigo e prometo, com as ajuda de Deus, a amá-la, sustentá-la e tê-la sempre comigo, cumprindo os deveres de um marido fiel enquanto Deus me der vida.

Eu, (nome da mulher, profissão ou ofício e estado, idade, naturalidade e legitimidade, filiação e respectiva naturalidade), aceito (nome do homem, respectiva identificação) como meu único e verdadeiro marido, obrigando-me, pela ajuda de Deus, a amá-lo, honrá-lo e servi-lo, cumprindo os deveres de uma mulher fiel enquanto Deus me der vida.

E nós nos obrigamos a ter e reconhecer sempre por nossos filhos legítimos os que Deus nos der em resultado deste contrato, o qual abaixo assinamos com testemunhas, e nos obrigamos a casar-nos conforme as leis do País, logo que estas reconheçam uma forma de casamento que não se oponha às leis divinas nas Escrituras Sagradas.

Essa iniciativa de disciplinamento das práticas socioafetivas regulado por pressupostos ético-religiosos tinha uma circunscrição restrita, pois se respaldava em uma deliberação da própria comunidade do reverendo Kalley, a Igreja Evangélica Fluminense, que sendo de modelo congregacionalista, ${ }^{29}$ havia deliberado em 1858 a regulamentação da associação matrimonial entre seus membros, estabelecendo:

\footnotetext{
${ }^{28}$ CARDOSO, Douglas Nassif. Robert Reid Kalley. Médico, missionário e profeta. São Bernardo do Campo: IMS, 2001.

${ }^{29} \mathrm{O}$ congregacionalismo tem origem na Reforma religiosa do século XIX, desenvolvendo-se principalmente na Holanda, na Inglaterra e depois ainda mais nos Estados Unidos. Prefigurava a autonomia plena das comunidades locais (congregaçôes, daí o nome) e o caráter apenas associativo e fraterno das federaçôes que as congregavam.
} 
Não havendo lei brasileira pela qual os cristãos possam casar-se sem seguir os ritos da Igreja Romana, que (conforme o juízo desta Igreja Evangélica) estão opostos ao Evangelho, deliberou-se e determinou-se que seriam considerados honradamente casados aqueles que, não havendo embaraço algum que deve proibir o casamento, se unirem por um contrato escrito, e assinado perante testemunhas competentes, em que o homem e a mulher se ligarem para cumprir fielmente e mutuamente os deveres que, conforme os preceitos do SENHOR, cabem ao marido e à mulher, e se obrigarem a casar conforme as leis do país, logo que nestas se acharem regras pelas quais possam casar-se sem ofender a consciência.

Não se julgou que tais contratos assegurassem efeitos civis ou fossem tidos por casamentos na vista dos tribunais do país, mas sim que na vista de Deus são casamentos verdadeiros e que devem ser reconhecidos como tais pela Igreja.

César afirma que "muitos contratos de casamento acatólicos foram celebrados mediante esta fórmula", ${ }^{30}$ uma vez que a legislação de amparo aos protestantes, como vimos, só foi promulgada em 1861/1863, e somente com o Decreto $\mathrm{n}^{\mathrm{o}} 9.896 / 1888^{31}$ se legalizaria definitivamente.

O lugar social do debate sobre a mobilidade jurídica e de assimilação religiosa nas origens do protestantismo brasileiro foi indicado por Azevedo como "momentos em que outras doutrinas foram propostas à naçáo como sucedâneas da fé cristã, para alicerçarem o espírito público e o civismo", ${ }^{32}$ que não se restringiam às intençóes religiosas dado que as crenças que se utilizam para decifração da realidade possuem conteúdo político. Para o Estado, o pluralismo religioso cumpria seu papel porque a religião também se destina a motivar os sujeitos e a premiar a cidadania que favorece a ordem. No caso, como religião cristá, o protestantismo era bem-vindo ao mobilizar o catolicismo para o enfrentamento doutrinário, ocupando-o menos de obstar o regalismo do Estado imperial.

Por isso mesmo, a assimilação de todo esse arcabouço jurídico não se faria sem a resistência católica, como se observa das discussões a seguir. Em Pernambuco, a igreja católica recebia resposta de sua arguição quanto à celebração de um casamento acatólico, passados 23 anos do Decreto no 3.069/63:

Tenho à vista o ofício de V. S ${ }^{a} \operatorname{Revd}^{\underline{a}}$ de hoje datado, em que citando o artigo publicado no Diario de Pernambuco de ontem sobre o casamento de Abdon Américo de Araújo com Amélia Ma de Figueredo Luna pede providências em ordem de não ser celebrado tal casamento pela Igreja Evangélica Batista sita a rua Direita, desta Cidade, vista ter aquele indivíduo desonrado uma

${ }^{30}$ CÉSAR, Salustiano Pereira. O congregacionalismo no Brasil. Fatos e feitos históricos. Rio de Janeiro: OMEB, 1983.

${ }^{31}$ Referente aos direitos políticos.

${ }^{32}$ AZEVEDO, Thales. A religiáo civil brasileira. Petrópolis, RJ: Vozes, 1981, p. 10. 
pobre moça da qual tem um filho, sujeitando-se a ofendida, entretanto, a receber a quantia de um conto de reis como reparação ao dano sofrido em sua honra.

Devo dizer a V. S ${ }^{\underline{a}}$ Revdํㅗ que, em face do disposto no Decreto nº 3.069 de 17 de abril de 1863 artigos 58 e 59, somente ao juízo civil, e não a esta chefatura, cabe providência no sentido de ser obstado o projetado casamento. ${ }^{33}$

Mas, com um hiato temporal de duas décadas para que a norma se fizesse efetiva, ao governo imperial ainda se recorria para impugnar a legislação, como demonstra a carta do bispo de Pernambuco, mas sem sucesso, pois assistiria a promulgação do decreto definitivo dois meses depois. Diz o bispo:

A bem dos interesses desta diocese de Pernambuco, rogo a V. Exª que se digne a tomar em consideração não só a representação que dirigi ao Governo Imperial em 26 de novembro de 1886 sobre casamentos de católicos celebrados por ministros acatólicos, mas também a que dirigi em 31 de março do ano passado (...) relativa à hipoteca por parte dos fabriqueiros das matrizes. A primeira questão encerra questão gravíssima, que se entende como a validade de casamentos e afeta elevados interesses das famílias. Pelo exame daquela representação V. Ex ${ }^{\underline{a}}$ verá quanto urge coarctar a amplíssima faculdade concedida em favor do improvisamento dos ministros acatólicos e do intrometimento deles nos casamentos dos católicos, que por não poderem casar segundo as leis da Igreja e do Estado, recorrem a esse meio abuseiro de casamento (...). Peço a V. Ex $x^{\underline{a}}$ que se digne a firmar doutrinas claras e decisivas a respeito de um e de outro dos aludidos assuntos. ${ }^{34}$

A problemática da atribuição de direitos e reconhecimento seria um expediente inevitável dos debates parlamentares na nossa primeira organização jus-constitucional, como temos acompanhado, e a Assembleia guardava uma peculiaridade na perspectiva religiosa, tendo 20\% de clérigos na Casa, classe letrada no país.

Neste ponto o conceito de Bourdieu de campo religioso pode ser útil para vislumbrar os interesses em disputa na questão da liberdade religiosa no debate político. ${ }^{35}$ Para ele, uma das principais características dinamizadoras do campo religioso é a concorrência entre instâncias religiosas diferentes que, todavia, não se fechavam no plano religioso e atendiam ao conflito de dois projetos de sociedade. Enquanto o credo institucionalizado combate a entrada de religióes concorrentes, a existência da seita coloca em questão o monopólio dos bens de salvação. Remisso à sociologia da religião weberiana, Bourdieu sugere que, diante de doutrinas concorrentes, cada comunidade valoriza "signos distintivos e discriminatórios" com a fina-

\footnotetext{
${ }^{33}$ AAOR. Arquivo da Cúria Metropolitana da Arquidiocese de Olinda e Recife. Correspondências Oficiais (CO) e Correspondências Expedidas (CE) 1860-1891, CO 11/09/1863.

${ }^{34}$ AAOR. Correspondências Oficiais (CO) e Correspondências Expedidas (CE) 1860-1891, CE 11/01/1888.

${ }^{35}$ BOURDIEU, Pierre. A economia das trocas simbólicas. São Paulo: Perspectiva, 2005.
} 
lidade de dificultar a adesão de seus adeptos à religiáo adversária ou de se apresentar como superior às concorrentes, evidente no parlamento.

A Constituição previa inicialmente uma maior abertura para a dissidência religiosa, já a partir do direito de nacionalidade, informando nos $\$ \$ 7$ e 8 do art. 5o: "Sáo brasileiros: estrangeiros naturalizados seja qual for a sua religião." Além disso, é muito importante perceber que no texto em elaboração em 1823 a fixação dos direitos individuais citava especificamente a liberdade religiosa como se vê no art. 14 do projeto: "A liberdade religiosa no Brasil só se estende às comunhôes cristâs, todos os que as professarem podem gozar dos direitos políticos do império." Na discussáo do art. $7^{\circ}$ o padre Henrique de Resende, de Pernambuco, defendia o estabelecimento da liberdade religiosa porque "era necessária" com regulamentação posterior, pois se deveria ter "logo de princípio estas garantias, assim mesmo genericamente recebidas, e depois iremos fazendo as exceçôes necessárias". ${ }^{36}$

A argumentação dos defensores da tolerância religiosa apelava ao sentido da religiáo associada ao Direito natural. Em 10 de outubro, o padre Muniz Tavares afirmava que a liberdade religiosa é "um dos direitos mais sagrados que pode ter o homem na sociedade", e que a religiáo não podia ser imposição legal porque "a religiấo é fruto da persuasão e a força pública nunca persuadiu", ${ }^{37}$ contradito pelo padre Rodrigues Costa:

(...) quem uma vez abraçou a religiáo católica não pode admitir um culto diverso, nem consentir que se levante altar contra altar na mesma nação (...) não há religiáo alguma em que a apostasia náo seja crime (...) os deputados foram eleitos para sustentar os direitos do povo, e não para contrariar seus sentimentos, princípios e deveres (...) [os deputados] devem resistir ao perjúrio que esta liberdade religiosa implica. ${ }^{38}$

Muniz Tavares, apoiado por Carneiro da Cunha e Vergueiro contra-argumentava que se as garantias estavam previstas em lei (art. 16), portanto, não há traição ou crime tipificado, todavia é obrigação do Estado proteger "claramente todos os seus súditos, seja qual for a religião que seguirem", reiterando que, do jeito que propunham os antagonistas da liberdade religiosa, os estrangeiros tinham mais direitos no país do que os nacionais, pois podiam exercer sua liberdade religiosa.

Mas o debate não se esgotava. Os que defendiam as prerrogativas da religiáo do Estado contra a liberdade civil-religiosa, capitaneados por Cairu, insistiam que não se pode igualar os desiguais, católicos e protestantes. Cairu reincidiu seu argumento, que liberdade religiosa "não tem sido demandada pela nação", e na distinção entre liberdade religiosa e de consciência, esta última fora da alçada da lei e, portanto, não se justificava admitir que um brasileiro pudesse "tornar-se herege ou cismático" com apoio constitucional, avisando:

\footnotetext{
${ }^{36} \mathrm{AC}, 01 / 10 / 1823$.

${ }^{37}$ AC, 08/10/1823.

${ }^{38} \mathrm{AC}, 08 / 10 / 1823$.
} 
Se neste império houvesse grande multidão de brasileiros, sectários das diversas comunhôes cristâs, talvez seria política a declaração da tolerância delas e sua participação nos direitos políticos (...) Porém no Brasil nem existe a vasta instrução que distingue os países mais civilizados, que serviria de antídoto contra os desvarios dos infiéis, nem há ostensivamente nacionais que tenham a fatuidade de professar luteranismo, calvinismo e outras seitas dissidentes da religião católica. Portanto, a concessão do artigo da liberdade religiosa é uma liberdade pródiga, não suscitada pela nação, uma singularidade inaudita e nem ainda reclamada por uma considerável fração dos cidadãos brasileiros (...) Considere esta augusta assembleia em sua sabedoria e prudência quais seriam os efeitos da liberdade constitucional de qualquer cidadão professar as religiōes luteranas, calvinistas etc. ${ }^{39}$

Maciel da Costa entrara no debate na sessão anterior dizendo que o Brasil "tem a felicidade de não contar no seio de sua grande família nem uma só seita, das infinitas que há, de protestantes", defendendo a incompetência da constituinte para discutir temas de religião: "a assembleia não tem prerrogativa para estabelecer os direitos absolutos de livre escolha da religião" ${ }^{40} \mathrm{~A}$ competência da assembleia em matéria religiosa foi defendida pelo deputado Antonio Carlos, pois se a Assembleia pode outorgar outros direitos, pode fazê-lo em relação à matéria religiosa.

$\mathrm{O}$ art. $7^{\circ}$ foi aprovado em 10 de outubro e partir do dia 29 do mesmo mês se passou a discutir os art. 14, 15 e 16 e o texto substitutivo de d. Caetano Coutinho do seguinte teor:

Art. 14 - Ninguém será perseguido por suas opiniões religiosas, uma vez que não ofendam as leis e os costumes

Art. 15 - A religião da nação brasileira é a católica apostólica romana, única mantida pelo estado.

Art. 16 - Algumas outras religióes serão toleradas, quando se verificarem motivos justos e urgentes, e o seu culto particular ou público será determinado por lei.

\section{E outro substitutivo do deputado Antonio Carlos:}

14 - Cada membro das confissóes cristãs pode professar a sua religião no recinto destinado para este fim. Todos os que professam estas comunhões podem gozar dos direitos políticos.

15 - As outras religiōes além da cristã são apenas toleradas e só lhes compete o culto doméstico; e a sua profissão inibe o exercício dos direitos políticos.

16 - A religião católica apostólica romana é a religião do estado e a única mantida por ele, e só a ela compete o culto externo fora das igrejas.

Este foi texto aprovado em 6 de novembro, exceto com as indicaçôes em itálico.

\footnotetext{
${ }^{39} \mathrm{AC}, 08 / 10 / 1823$.

${ }^{40} \mathrm{AC}, 08 / 10 / 1823$. 
No debate que precedeu a aprovaçãa, a habilidade de Cairu voltou à cena sugerindo contradiçấo da norma com outro dispositivo em discussáo, o art. 24. Se os católicos eram punidos por heterodoxia, por que só os católicos? E como obrigar o imperador a manter uma religião se aos brasileiros é facultado recusá-la? Conclui pela distinção entre perseguição e concessão: dissidentes não seriam perseguidos, mas não lhes seriam facultadas concessões.

Ninguém duvidava da "necessidade de atrair imigração europeia que venha a suprir o que a agricultura perde". No exterior, por sua vez, a apreensão para a vinda dos estrangeiros dizia respeito também à liberdade religiosa. Propõe-se nova redação: "A religião católica apostólica romana é a religiáo do Estado e única mantida por ele. É, porém, permitida no império a livre tolerância de todas e quaisquer seitas religiosas." Mas a problemática se encerra no âmbito constituinte com a dissolução da Assembleia em 12 de novembro, com o formato da Constituição petrina na redação mencionada. Estavam ainda abertas a questão dos casamentos, sepultamentos e participação política.

O art. 95 fixava que todos os que estavam qualificados como eleitores poderiam ser eleitos para o parlamento, porém, excetuava da regra "os que não professam a religião do Estado", restrição não havida no projeto proposto pela Constituinte, senão para credos não cristãos. Finalmente a salvaguarda dos direitos civis acatólicos firmava-se limitadíssima nos termos do art. 179: "Ninguém poderá ser perseguido por motivo de religiáo, uma vez que respeite a do estado."

Quando Robert Kalley chegou ao Brasil em 1855, tinha sua própria estratégia de propagação religiosa, mas as restriçôes de certas autoridades locais impuseram um novo instrumento para sua missão: a interpelação ao Estado para que construíssem uma interpretação dos dispositivos constitucionais referentes à liberdade religiosa e de culto. Kalley elaborou um questionário com onze questóes e o remeteu a três dos mais destacados juristas, Urbano Pessoa de Melo, Caetano Alberto Soares, à época presidente do IAB, e Thomás Nabuco, para caracterizar ou não a violaçấo às leis do país pelas suas práticas religiosas. Indagava:

Os cidadãos brasileiros adultos têm ou não a liberdade perfeita de seguirem a religiáo que quiserem?

Se algum deles consultar alguma pessoa que não segue a religiáo do Estado e esta pessoa lhe explicar sua crença, será um ou outro incurso em qualquer pena legal?

Será criminoso aquele que nesse caso aconselhar o cidadão brasileiro a adotar uma religiáo que não seja a do Estado?

O caso será o mesmo estando a pessoa em sua casa ou fora dela, em público ou em particular? Se um cidadáo brasileiro unir-se a qualquer outra comunháo que não seja a do Estado, será por isso incurso em qualquer pena, seja debaixo do título de blasfemo, apóstata ou outro qualquer? Os membros da comunháo que o receberem (ou qualquer deles) serão por isso incursos em qualquer pena da lei?

É lícito aos estrangeiros seguir o seu culto doméstico em suas casas particulares? 
Se algum dos seus amigos brasileiros quisesse estar presente com eles, tornar-se-ia por isso o seu culto criminoso?

Se o culto estrangeiro estivesse em uma casa sem forma alguma de templo, mas com entrada franqueada àquele que quiser — sem limitar-se aos amigos do morador — seria criminoso? Um estrangeiro pode ser obrigado a sair do sítio onde mora, ou ser deportado do país à vontade do governo sem culpa formada?

O que se deve entender por publicamente e reunióes púbicas nos artigos 276 e 277 da Carta Constitucional?

"As respostas dos três juristas aos quesitos formulados, eram, em alto grau, satisfatórias." ${ }^{1}$ Os incidentes pontuais de perseguição havidos levaram a uma iniciativa formal por parte do governo imperial, pois em 19 de outubro de 1861 "era distribuída uma circular do chefe de polícia da capital lembrando o respeito devido aos cultos não católicos, desde que estes tivessem lugar em locais particulares sem caráter de templo, como acontecia então” ${ }^{42}$

\section{Reediçóes: o problema recorrente}

Dois pontos principais do ponto de vista jurídico-social eram os casamentos e os sepultamentos de acatólicos. Lembra Leonard que "a legislação vigente (...) atrasadíssima, só reconhecia legítimos, dos casamentos contraídos no império, os celebrados em conformidade com as disposiçóes do Concílio de Trento". ${ }^{33}$ Por duas vezes a questão dos casamentos acatólicos subiu para a apreciação do Conselho de Estado, em 1853 e 1856, pela provocação das circunstâncias, nas duas vezes o Conselho se pronunciou pela necessidade de regulamentação da condição dos acatólicos. A base do argumento do Conselho era o princípio constitucional da tolerância religiosa. Argumentava:

A Constituição estabeleceu a tolerância religiosa para todos os cultos (...) O país carece da colonização e de promover a imigração: esta não nos vem somente de países católicos (...) Em São Paulo, consta oficialmente ao governo que não só os protestantes entre si, mas até católicos ignorantes têm descansado completamente na validade de casamentos contraídos por meras escrituras que nossas leis não reconhecem; em Petrópolis têm-se contentado com o casamento e fórmulas de uma só Igreja; de sorte que, enquanto um dos cônjuges se reputa ligado, o outro se considera livre. Isto é revoltante e faz reconhecer a necessidade de pronto remédio (...) Dois são os meios de as diminuir (as dificuldades): um, obter as dispensas das disparidades de culto

\footnotetext{
${ }^{41}$ ROCHA, João Gomes da. Lembranças do passado. Rio de Janeiro: CBP, 1941, p. 95, 4v.

${ }^{42}$ LEONARD, Emile-G. O protestantismo brasileiro. São Paulo: Aste/Juerp, 1981, p. 51.

${ }^{43}$ Ibidem, p. 66.
} 
para se celebrarem os casamentos religiosos mistos; outro, o casamento civil como contrato que produza efeitos meramente civis, deixando a consciência dos contraentes a irregularidade dessa união no foro interno (...) Não há outro recurso senão o casamento civil. ${ }^{44}$

Essa recomendação era válida apenas para os casamentos acatólicos e

(...) para os católicos, só nos casos de casamentos mistos, quando não tenham preferido ou conseguido realizá-lo perante a Igreja Católica (...) limitando-se assim o casamento civil a duas hipóteses, que a seção propóe, teria a vantagem de simplificar a questão dos julgamentos sobre nulidade, divórcios, impedimentos etc. ${ }^{45}$

porque o direito canônico era aplicável somente aos casamentos entre professantes católicos, assim, mesmo sem o rito religioso os nubentes poderiam ser considerados casados pela lei civil.

Tardiamente, seguindo as sugestóes do Conselho, o governo apresentou em julho de 1858 o projeto de regulamentação do casamento acatólico:

Art. $1^{\circ}$ - O casamento entre pessoas que não professam a religião católica apostólica romana serão feitos por contrato civil, podendo seguir-se o ato religioso, se este não houver sido celebrado antes. Art. 2- - O casamento civil também poderá ser contraído quando um dos cônjuges for católico e outro não. Fica, porém, entendido que, se nessa hipótese preferirem celebrar o casamento religioso na Igreja Católica, o poderâo fazer independentemente do contrato civil, produzindo o religioso, além do vínculo espiritual para o católico, todos os efeitos civis para ambos tão completamente como se tivesse havido contrato civil.

Art. 3o - O contato civil seguido da comunicação dos esposos, assim na hipótese do artigo 1o como do artigo $2^{\circ}$, torna o matrimônio indissolúvel e produz todos os efeitos civis que resultam do que é contraído segundo as leis do país e dos costumes do império.

Art. $4^{\underline{o}}$ - Os casamentos mistos, ou entre pessoas estranhas à Igreja Católica, bona fide, contraídos antes da publicação da presente lei, por escritura pública, ou celebrados na forma de alguma religião tolerada, se consideram ipso facto ratificados para os efeitos civis, como se tivessem sido contraídos ou celebrados na forma prescrita para os casamentos civis, uma vez que a isso não se oponham impedimentos tais que os devam embaraçar, segundo o que houver regulado o governo conforme do $\$ 1^{\circ}$ do art. $6^{\circ}$.

$\$$ Único. Dentro, porém de um ano, contado da publicação da lei, será livre dissolvê-los, quando o permita a religião, segundo a qual se tiver celebrado a cerimônia religiosa. Passado esse período, ficarão indissolúveis.

\footnotetext{
${ }^{44}$ RODRIGUES, José Carlos. Religiōes acatólicas. Memórias. Rio de Janeiro: Imprensa Nacional, 1903, p. 67. ${ }^{45}$ AS, 11/02/1861.
} 
Art. 5ํ- Serão reconhecidos válidos, e produzirão todos os efeitos civis, os casamentos celebrados fora do império, segundo as leis do país onde houverem sido contraídos.

Art. 6o - É o Governo autorizado:

$\$ 1$ o Para regular os impedimentos, nulidades, divórcios quod thorum e forma da celebração dos referidos casamentos como contratos civis.

$\$ 2$ ㅇ Para regular e organizar os registros dos mesmos casamentos, assim como dos nascimentos que deles provierem. ${ }^{46}$

Outra vez, na justificação do projeto pelo Ministro da Justiça, além "da segurança das famílias, seu futuro, sua sorte (...)" aparece a questão da imigração que encontrará "barreira insuperável na satisfação dessa necessidade, se porventura os estrangeiros não puderem contrair laços de família com certeza de sua legitimidade”.

O padre Pinto de Campos apresentou parecer, mas que, além do rebusco histórico na legislação canônica e na patrologia, nada acrescentou. Tanta polêmica havida que com o encerramento dos trabalhos parlamentares somente no ano seguinte o projeto foi discutido, sendo objeto de duas representaçóes do episcopado contra a iniciativa.

$\mathrm{O}$ arcebispo da Bahia, d. Romualdo Seixas, tinha como certa a origem do pensamento que justificava a questão do casamento civil legada "pelo protestantismo ao filosofismo moderno (...)" e era ele, o protestantismo, o seu beneficiário, representando ameaça à ordem que concretizava como "funestas consequências do proselitismo protestante, que como é notório, se acha empenhado em descatolizar o país e já infelizmente conta algumas conquistas”, pela ignorância popular. ${ }^{47}$ Considerava inoportuno a importação de uma legislação favorável aos casamentos de acatólicos, "para um país eminentemente religioso cujos hábitos inveterados e seu pacto fundamental, que proclamou a religião católica apostólica romana como religião do império (...) não pode, sem perigo, comportar uma semelhante inovação". 48

$\mathrm{O}$ mais curioso na argumentação de d. Romualdo é a apresentação de uma questão teológica. Entendia que os protestantes eram “dissidentes” da fé católica, não uma religião distinta, eram fruto da "quebra da unidade" eclesial, portanto, ainda "súditos da Igreja, bem que refratários”, por isso, sujeitos à legislação canônica. É justo também que se reconheça que d. Romualdo estava à frente de outros debatedores católicos na questão da fixação de competências. Mesmo que "laborando em erro", com uma "medida equivocada", lembrava ele que não se podia negar ao Estado "os direitos e atribuiçóes que lhe competem sobre os efeitos civis do matrimônio", completando: "Não! A igreja é a primeira a reconhecê-

\footnotetext{
${ }^{46}$ AS, $17 / 03 / 1858$.

47 SEIXAS, Romualdo Antônio de. Obras completas. Salvador: Lellis Masson, 1859, p. 383. Muito embora se cultive o mito da associaçáo do protestantismo com os setores menos instruídos da sociedade, e de fato o protestantismo tenha tido tal apelo, há uma marcada projeçáo do protestantismo entre setores médios, militares, intelectuais, jornalistas, etc., inclusive, em menor escala, entre alguns membros da aristocracia nacional.

${ }^{48}$ Ibidem, p. 388.
} 
-los e respeitá-los (...) é extensa a jurisdição. O que a Igreja não pode aceitar é que o ato civil por si só constitua o matrimônio", ${ }^{49}$ nem há antinomia do direito canônico com o direito civil. A ponderada postura de $\mathrm{d}$. Romualdo foi usada inclusive por defensores do projeto governamental, e com a alternância do gabinete em 1859 tomou a forma de um substitutivo, que não se voltava à questão dos nubentes de credos distintos, considerado problema inexpressivo do ponto de vista quantitativo, mas aceitou o casamento civil para os professantes católicos e sua indissolubilidade. $\mathrm{O}$ substitutivo tomara a seguinte forma:

Art. 1ำ Os efeitos civis dos casamentos celebrados na forma das leis do império serão extensivos: $\$ 1^{\circ}$ Aos casamentos que se fizerem por contrato civil entre pessoas que não professem a religião católica apostólica romana, guardadas as solenidades de que trata o art. $4^{\circ}$

$\$ 2^{\circ}$ Aos casamentos feitos no império bona fide antes da publicação da presente lei por simples contrato, ou perante pastores de religióes admitidas, não havendo entre as partes impedimento que, segundo as leis em vigor, devam obstar o matrimônio.

$\$ 3^{\circ}$ Aos casamentos que se contraírem fora do império com as solenidades admitidas nos respectivos países e conforme as leis a que os contraentes estejam sujeitos.

Art. $2^{\circ}$ - Os casamentos mencionados no art. $1^{\circ}$ serão indissolúveis quanto aos efeitos civis, desde que haja comunicação entre os esposos.

Art. $3^{\text {o }}$ - Os impedimentos aos casamentos entre pessoas que não professam a religião católica apostólica romana e de que trata o $\$ 1^{\circ}$ do art. $1^{\circ}$, as dispensas, os casos em que as mesmas são admissíveis, a separação dos cônjuges, educaçáo da prole e mais obrigaçóes dos cônjuges se regularão pelo direito em vigor em tudo que for aplicável.

$\$ 1$ 을 As dispensas dependerão da autoridade civil.

$\$ 2^{\circ}$ As questóes que se suscitarem acerca dos casamentos a que esta lei confere efeitos civis serão competência das justiças ordinárias.

Art. $4^{\circ}$ - O governo marcará as fórmulas e solenidades com que devam celebrar-se, afim de produzirem efeitos civis, os casamentos de que trata o $\$ 1^{\circ}$ do art. 1ำ, e regulará o seu registro e o de nascimento e óbitos, bem como a prova da existência dos casamentos mencionados nos $\$ \$ 2^{\circ}$ e $3^{\circ}$ do mesmo art. $1^{\circ}$.

Art. 5ำ - Ficam revogadas as disposições em contrário. ${ }^{50}$

Remetido o substitutivo ao Senado, Pereira de Vasconcellos, agora senador, e que tinha sido autor do mesmo projeto, defende o projeto original, dando conta que a proposta havia sido o resultado de exaustivo estudo, que além das demandas estrangeiras, duas vezes ouvira o Conselho de Estado e acusa de lacunar o substitutivo por não referir-se à questão

\footnotetext{
${ }^{49} \mathrm{Idem}$.

${ }^{50} \mathrm{AC}, 8 / 8 / 1859$. O resultado foi a acomodaçáo dos interesses do setor eclesiástico, reticente somente quanto à indissolubilidade do casamento acatólico, o que na verdade superava inclusive os interesses protestantes, mas também o cerceamento do projeto previsto originalmente.
} 
dos nubentes de credos distintos e nem fixar o foro judicial para apreciação das questôes relativas indissolubilidade do matrimônio, ${ }^{51}$ mas apesar disso, votaria no substitutivo porque temia que o país continuasse sem legislação alguma, esperando para breve nova e necessária apreciação do problema, concluindo: "É impossível acreditar que os protestantes sejam tão néscios que não vejam que a espécie sobre que pediam providência não fica regulada — que continua o mesmo caos, incerteza e inquietação, pelo que diz respeito ao futuro da família." 52

O governo foi acusado de fraqueza pelo senador Barros Leite, de Alagoas, o que dava causa às resistências à regulamentação da matéria. $\mathrm{O}$ direito canônico pré-tridentino e a legislaçáo portuguesa, no seu entender, reconheciam a prerrogativa do Estado para legislar sobre este ponto, o problema era as condições impostas pelas leis da igreja para sua consecução.

O projeto é incompleto (...) A questão há de resolver-se quer o poder civil queira, quer não queira. E, senhores, não será necessário que o governo do Brasil faça passar uma lei protegendo os seus súditos protestantes? Ou será lei apenas para proteger os protestantes estrangeiros? (..). a Constituição diz que ninguém será perseguido por motivo de religiáo, entretanto na ocasiáo em que se precisa destas garantias elas são postergadas. ${ }^{53}$

Ainda se interrogou, sem sucesso, se ao fixar a religião católica apostólica romana como religião do Estado, não exigia obrigar todos os brasileiros a segui-la, tese do senador Manoel de Assis. Como indicamos, esse projeto substitutivo foi aprovado como lei em 1861, mas o governo não se apressou em regulamentá-la senão em 1863. Resolvida a questão dos casamentos acatólicos, do ponto de vista da legislação, nas províncias, na prática, não vigoraria até as vésperas da república, outras discussôes sobre liberdades civis ainda estavam pendentes.

Bandeira histórica do liberalismo, em carta programática de 1869 a "liberdade de consciência" fez Silveira Martins e o baráo de Villa Bella abandonarem o Gabinete Sinimbu pela sua resistência em incluir na reforma eleitoral ${ }^{54}$ a participaçáo de acatólicos. Dizia Martins: "os deixa ficar somente porque professam religiáo diferente da do Estado, inferiores a condição dos ingênuos nascidos do ventre escravo".

Mas havia mesmo quem dissesse, como se atribui a C. Ottoni, que:

(...) era absurdo fechar-se a porta aos acatólicos que são cristãos, que professam sua fé livremente, e abri-la a esses muitos católicos nominais, que têm tomado assento no parlamento e que eram

\footnotetext{
${ }^{51}$ Francisco Vasconcellos tenta justificar sua tese lembrando que ao protestante era legítimo a separação em caso de adultério, e ao católico, não, por disposição tridentina; portanto, o projeto proposto era uma proteção ao católico que se casasse com um acatólico.

52 AC, 8/9/1959.

${ }^{53} \mathrm{AC}, 8 / 9 / 1959$.

${ }^{54}$ Era a preocupação do presidente do Conselho, Cansanção de Sinimbu, comprometer a reforma com um tema tão polêmico.
} 
ora livres pensadores, ora sectários das teorias do protoplasma, geração espontânea, aniquilação do espírito pela decomposição da matéria, mas que se diziam católicos somente por faltar-lhes a coragem de abjurar uma religião em que não acreditam..$^{55}$

Outra face não superada era a liberdade de culto. Tardiamente, em 1887, o senador Silveira Martins apresentou um projeto de lei para a liberdade de cultos. ${ }^{56}$ Apoiado por Taunay, Ouro Preto, Costa Pereira e Cotegipe, entre outros, solicitava a revogação da segunda parte do art. 5을 da Constituição, argumentando que era "o indiferentismo religioso — que é isto que reina no país" a causa da intolerância que justificava aqueles dispositivos, porque "a pátria não é convento e deve deixar a estes mistérios à consciência de cada um ou ao clero de cada religiáo". $57 \mathrm{O}$ argumento de Costa Pereira respondia ao acento numérico do protestantismo: “(...) hoje que temos em nosso grêmio número considerável de estrangeiros e nacionais que professam religióes acatólicas, não há motivo para não se aprovar o projeto (...) pois que não faz mais que traduzir em lei um fato geral e pode-se dizer costumeiro no Brasil." 58 Taunay acrescenta: "É necessário que o governo não cuide apenas da imigração estipendiada e esta de origem somente católica, devemos apelar para outro elemento preciosíssimo (..). cumpre cuidarmos da promulgação das leis do casamento civil, secularização dos cemitérios, liberdade de cultos (...) — é uma lei de moralidade — , esta do casamento civil." ${ }^{59}$

Mas se havia esta propensão mais ou menos generalizada, a hierarquia católica foi a voz dissonante, principalmente na representação apresentada ainda em agosto pelo bispo do Pará, d. Macedo Costa. Argumentava que, com a história nacional, a herança colonial, previa a Constituição que continuava o catolicismo a ser a religião do Estado, tese para defender a união entre os dois poderes. Afirmava ainda a precedência do catolicismo em relação ao Pacto Fundamental, e que as associaçóes religiosas, na condição de cultos tolerados, já eram beneficiárias, que, aliás, até “extrapolavam suas prerrogativas”, portanto, o projeto era "uma preparação para a abolição completa do catolicismo como religião do Estado", afinal de contas, "o que é o protestantismo senão um desfibrador de crenças, senão uma porta aberta para o racionalismo puro?” ${ }^{60}$ Não poderia o católico

\footnotetext{
${ }^{55}$ RODRIGUES, José Carlos. Religióes acatólicas. Memórias, op. cit., p. 81.

${ }^{56}$ Nesse particular, importa lembrar que Silveira Martins guardava certas ambiguidades em sua prática política, transitando entre a condição monarquista-liberal-monarquista, apoiando o fim do Gabinete Ouro Preto, mas não a república que lhe seguiu, e nunca advogou pelos direitos dos protestantes especificamente. É mais factível entender seu interesse no grande contingente de luteranos em seu estado, o Rio Grande do Sul, como pretendida base política, pois, como afirma Isaia, ele era "porta-voz da estratégia de ampliação do predomínio Liberal no Rio Grande do Sul [que tornava eleitor o protestante] pugnando pela equiparação de direitos políticos entre católicos e protestantes" (Cf. ISAIA, Artur César. Catolicismo e autoritarismo no Rio Grande do Sul. Porto Alegre: EdPUCRS, 1998, p. 40, grifo nosso).

${ }^{57} \mathrm{AC}, 6 / 6 / 1887$.

${ }^{58} \mathrm{AC}, 6 / 6 / 1887$.

${ }^{59} \mathrm{AC}, 10 / 3 / 1887$.

${ }^{60}$ COSTA, A. de Macedo. Representação à Assembleia Geral Legislativa. Rio de Janeiro: Lamounier, 1864, p. 11.
} 
admitir a liberdade de cultos pela origem divina do catolicismo: "se não há uma religião divina e obrigatória para todos os homens, não há religião, não há Deus”. Mas as reaçôes náo foram admitidas e o projeto entrou em vigência, sem nem mesmo produzir tantos debates na Câmara, sob influxo do novo gabinete liberal de Ouro Preto. A conclusão é de Rodrigues:

É, pois, fora de dúvida que a liberdade de cultos era matéria assentada entre os dois partidos políticos do império, quando este caiu em 15 de novembro do mesmo ano. Pode-se afirmar que durante todo o regime da monarquia essa reforma foi uma aspiração do país, náo realizada mais cedo em consequência da geral apatia por estas questôes dos princípios religiosos, e porque era ainda pouco apreciável, politicamente, o número de protestantes e sectários de outros cultos que exigissem a liberdade destes. ${ }^{61}$

Wilson Martins afirma: "Estava claramente implantado, desde a constituinte de 1823 aquilo que meio século mais tarde iria receber o nome de 'Questão Religiosa", ${ }^{2}$ e mais, a questão religiosa reaparecia sobre os mais "inesperados aspectos, um deles o dos casamentos mistos, inscrito em um triângulo de que a religiáo oficial era um dos lados, os outros dois sendo constituídos pela falta de um código civil e pela chegada cada vez mais volumosa de trabalhadores livres estrangeiros". ${ }^{63}$

É tese de Ribeiro que os direitos foram se constituindo ao longo do século XIX em luta constante por uma população reivindicante, podemos dizer que houve um avanço da consciência de direitos e da luta por eles, construída de forma propositiva, como referimos, e que o que se entendia por direitos estava além do estabelecido nas leis e na Constituição. A autora sugere que, no império, era tênue o liame que relacionava direitos e política com categorias cidadãs ativas e passivas, sendo privilégio das primeiras os direitos à participação, os demais restritos aos direitos civis. Entretanto, isso era a letra da lei na Carta de 1824, em atendimento às elites, prevalecia o entendimento pelo conjunto da população que os direitos extravasava esses limites. ${ }^{64}$

A ausência da codificação civil, prevista sua elaboração e vigência no $₫ 18$ do art. 5o da Constituição era responsável pelo limitado provimento dos direitos civis, mesmo com as

\footnotetext{
${ }^{61}$ RODRIGUES, José Carlos. Religióes acatólicas. Memórias, op. cit., p. 84.

${ }^{62}$ MARTINS, Wilson. História da inteligência brasileira. São Paulo: TAO, 2001, t. II, p. 146. Não é possível acompanhar teses como a de Scampini, reproduzida por Casamasso, de que "a Questáo Religiosa foi o acontecimento de maior repercussão na história brasileira". SCAMPINI, José. A liberdade religiosa nas constituiçōes brasileiras. Petrópolis, RJ: Vozes, 1978, p. 41. CASAMASSO, Marco Aurélio Lagreca. Estado, igreja e liberdade religiosa na "constituição política do imperio do Brazil", de 1824. Anais do XIX Encontro Nacional do CONPEDI. Fortaleza, 9 a 12 de junho de 2010, p. 6176.

${ }^{63}$ MARTINS, Wilson. História da inteligência brasileira, op. cit., t. III, p. 1.

${ }^{64}$ RIBEIRO, Gladys Sabina (Org.). Brasileiros e cidadãos: modernidade política, 1822-1930. São Paulo: Alameda, 2008.
} 
tentativas de sua elaboração com Teixeira de Freitas (1858), Felício Santos (1881) e Coelho Rodrigues em $1897 . .^{65}$

Também é importante ressaltar as advertências de José Murilo de Carvalho de que a cidadania demandada no império também possuía a dimensão que remetia a valores e as práticas sociais definidoras da esfera pública, um processo formativo da consciência social que apontava para as formas de participação dos indivíduos na sociedade, remissa aos modelos liberais de finais do século XVIII e o assujeitamento de direitos, pretensão de direitos baseados na tradição e no processo histórico brasileiro expressos nos diversos movimentos liberais de fins do XVIII e inícios do XIX até o estabelecimento da ordem republicana. ${ }^{66}$

Já no âmbito dos embates anteriores à Questão Religiosa (1872-1875) que visavam o esvaziamento do protagonismo político para a Igreja, o governo baixou dois decretos: o primeiro estabelecendo o censo demográfico-populacional e regulamentando o registro dos nascimentos e óbitos dos habitantes do império brasileiro (1851). Embora possa se considerar uma questão que suscita debates, até que ponto as iniciativas do Estado era o provimento direitos ou o esforço de maior controle social, sua ação reflexa de ampliação das prerrogativas civis em uma sociedade sob tutela leiga incidia positivamente sobre a construção da cidadania. O segundo (1863), que regulava o Decreto no 1.114/1861, estabelecia a extensão dos efeitos civis dos casamentos não católicos.

Porém, apesar da legislação, durante todo o Segundo Império a Questão Religiosa não foi posta em execução por razóes fortuitas ou pressão do catolicismo, constituindo-se este retardo na mantença da posição da Igreja e sua competência para confeccionar os registros civis do império. Segundo Mendes,

A Lei do Registro Civil e do Censo será prudentemente esquecida pelo Estado imperial. Nesta como em muitas outras ocasiōes no século XIX, os limites da intervenção do Estado serão demarcados pela "arte da separação" das reaçóes dos atingidos ou interessados.

No varejo, o Estado imperial continuava encontrando grandes dificuldades em obter estatísticas e realizar censos populacionais (OURÉM, 1885, p. 15). Além das dificuldades gerais de coordenação, de recursos e de pessoal que a tarefa de obter estatísticas censitárias em um território desmesurado evidentemente implicava, a experiência da lei de 1851 revelava ainda a operação de micromotivos daqueles que adivinhavam os propósitos a que os registros poderiam servir. ${ }^{67}$

Se de um lado os párocos eram veladamente hostis ao registro civil, que lhes ameaçava tomar emolumentos, de outro, a população desconfiava, sobretudo, das intençóes do gover-

\footnotetext{
${ }^{65}$ SANTOS, João Marcos Leitão. Inflexões em torno do pensamento jurídico de Antonio Coelho Rodrigues. Arius, Campina Grande, v. 19, n. 2, p. 38-70, jul./dez. 2013.

${ }^{66}$ CARVALHO, José Murilo. Cidadania no Brasil — o longo caminho. Rio de Janeiro: Civilização Brasileira, 2005. ${ }^{67}$ MENDES, Fábio Faria. A economia moral do recrutamento militar no império brasileiro. Revista Brasileira de Ciências Sociais, Rio de Janeiro, v. 13, n. 38, p. 8, 1998 (grifo nosso).
} 
no, considerando interesses obscuros de que pudessem, de algum modo, servir a propósitos de escravização do "povo mais miúdo".

Nos debates do Senado em agosto de 1870, o senador Pompeu Brasil advertia que substituir os padres na realização do registro civil tinha inconveniências. Dizia o senador:

Primeiramente, porque com efeito o registro é cristão, não é natural, isto é, o pároco registra o menino que se batiza, mas não registra o menino que nasce, é um registro de fatos católicos, não dos fatos naturais do homem: em segundo lugar, também tive pessoalmente experiência desse serviço, que por dez anos correu por minhas mãos uma série de assentos de batizados, casamentos e óbitos, e vi como se pratica este trabalho em nosso país, conheço que ele é imperfeito.

Não convém esquecer uma coisa, e é que nosso povo, habituado às práticas da religião, respeita os párocos nestas exigências. A religião, sr. presidente, como V. Ex $x^{\underline{a}}$ sabe, acompanha o homem desde o nascimento (...) o povo está acostumado a ver o ministro da religião intervir em todos os atos da vida humana, e por consequência não estranha que ele indague ou exija informaçóes necessárias para este lançamento. Mas se fazer isso por meio da autoridade civil, do subdelegado ou do escrivão ele talvez repugne fazê-lo, e daqui vem a contestação, a inexatidão do serviço, senão alguma explosão, certamente estúpida, como essa que ameaçou a tranquilidade pública em Pernambuco e Alagoas. ${ }^{68}$

Tornou-se corrente entre a população a inquietação e a perplexidade de se era realmente factível que "sem certidão deles não se poderá fazer uma criança cristã", deles, dos escrivães. ${ }^{69}$

Um ano mais tarde, em arguição no Senado, o visconde do Rio Branco, presidente do Conselho de Ministros, voltaria à questão.

O Sr. VISCONDE DO RIO BRANCO (presidente do conselho) — [sobre a lei] (...) SS. Exx. Não podem desconhecer as dificuldades práticas que se trata estudar e resolver do melhor modo possível.

O registro civil de que o nobre senador pelo Ceará (P. Otaviano) também não foi esquecido. Há dois projetos de regulamento, e estes trabalhos começaram durante o ministério de 16 de julho, mas o registro civil merece ainda mais escrupulosos estudos que recenseamento geral da população. O senado recorda-se do que aconteceu em 1851, é necessário preparar a população para este regulamento. ${ }^{70}$

\footnotetext{
${ }^{68}$ AS, 7/3/1870.

${ }^{69}$ Decreto de 1851, cuja tentativa de laicizaçáo dos registros de nascimentos, casamentos e óbitos esteve na base do movimento do Ronco da Abelha (1851/1852), no qual as populaçôes invadiram as igrejas para protestar contra o novo regulamento, rasgando os editais, intimidando os juízes de paz e as autoridades policiais para que não ousassem executá-lo, até o limite do enfrentamento com as forças de segurança.

${ }^{70}$ AS, $7 / 5 / 1871$.
} 
A reforma eleitoral viria em 1881, abrindo espaço para uma rarefeita representaçáo política do protestantismo. O estágio mais preciso dessa trajetória em torno dos direitos civis das populaçôes católicas ganharia novos contornos e novas capilaridades com a inauguração do modelo laicista instituído no regime republicano, ainda que sua consolidação se fizesse ao compasso de tantas intempéries, como as que se expuseram no Brasil imperial.

\section{Considerações finais}

Da exposição feita neste artigo emergem algumas questôes importantes para serem realçadas. Primeiro, o estado nacional brasileiro debateu-se em suas origens com a expectativa de um modelo liberal de organização social, conforme positivado no ordenamento jurídico, mas que esbarrava na herança religiosa católica que permeava culturalmente a sociedade nascente.

Assim, a presença do protestantismo durante o período imperial foi um importante elemento de reconfiguraçáo da ordem na medida em que fez surgir as demandas por novos espaços de acomodação para sujeitos sociais a serem agregados na vida societária, ao passo que também apontava para a quebra do monolitismo religioso.

Tal quebra, que incidia sobre a ordem social e jurídica, foi um importante espaço para a afirmação dos direitos civis no Brasil, não apenas para os acatólicos, mas para outros setores, notadamente, liberais e livres pensadores que estavam sob a tutela do agente religioso do estado, que operava naquele instantes como inibidor das liberdades individuais.

Por essas três razóes, principalmente, os debates suscitados pelos novos professantes religiosos haveriam de estar na base de uma nova ordem instituída durante a república, que prevalece até os tempos hodiernos.

\section{Fontes}

AAOR. Arquivo da Cúria Metropolitana da Arquidiocese de Olinda e Recife. Correspondências Oficiais (CO) e Correspondências Expedidas (CE) 1860-1891.

AC. BRASIL. Câmara dos Deputados. Anais da Assembleia Geral Legislativa do Império do Brasil. 1823.3 v. Brasília: Senado Federal, 1999.

AS. BRASIL. Congresso Nacional. Anais do Senado do Império do Brasil. Disponível em: $<$ http://www.senado.br>.

BRASIL. Código Criminal do Império do Brasil. 1830. Disponível em: <http://www. planalto.gov.br/ccivil_03/leis/lim/lim-16-12-1830.htm>. 
BRASIL. Decreto-lei de 20 de outubro de 1823. Dispoível em: <http://www2.camara.leg.br/ legin/fed/lei_sn/anterioresa1824/lei-40951-20-outubro-1823-574564-publicacaooriginal97677-pe.html>.

COSTA, Antonio de Macedo. Representação à Assembleia Geral Legislativa. Rio de Janeiro: Lamounier, 1864.

RODRIGUES, José Honório (Org). Atas do Conselho de Estado. Brasília: Senado Federal, $1973,14 \mathrm{v}$.

\section{Siglas}

AS - Anais do Senado

AAOR - Arquivo da Arquidiocese de Olinda e Recife

AC - Anais da Câmara

AS - Anais do Senado

\section{Referências bibliográficas}

AZEVEDO, Thales. A religião civil brasileira. Petrópolis, RJ: Vozes, 1981, p. 10.

AZZI, Riolando. A cristandade colonial: um projeto autoritário. Petrópolis, RJ: Vozes, 1987. BARROSO, Luis Roberto. O Direito Constitucional e a efetividade de suas normas: limites e possibilidades da Constituição brasileira. Rio de Janeiro: Renovar, 1990.

BOURDIEU, Pierre. A economia das trocas simbólicas. São Paulo: Perspectiva, 2005.

CARDOSO, Douglas Nassif. Robert Reid Kalley. Médico, missionário e profeta. São Bernardo do Campo: IMS, 2001.

CARVALHO, José Murilo de. A construção da ordem: a elite política imperial. Rio de Janeiro: Campus, 1980. . Cidadania no Brasil — o longo caminho. Rio de Janeiro: Civilização Brasileira, 2005. CÉSAR, Salustiano Pereira. O congregacionalismo no Brasil. Fatos e feitos históricos. Rio de Janeiro: OMEB, 1983.

CHAVANTE, Esdras Cordeiro. Tavares Bastos e a construção da liberdade religiosa Revista Brasileira de História das Religióes, Maringá, v. V, n. 15, jan. 2013. Disponível em <http:// www.dhi.uem.br/gtreligiao/pub.html>. Acesso em: 12 maio 2013.

CIARALO, Gilson. O tema da liberdade religiosa na política brasileira do século XIX: uma via para a compreensão da secularização da esfera política. Revista de Sociologia e Política, Curitiba, v. 19, n. 38, p. 85-100, fev. 2011. Disponível em: <http://ojs.c3sl.ufpr.br/ojs2/ index.php/rsp/issue/view/1502>. Acesso em: 6 jan. 2013. 
COSTA, Emília Viotti da. Da monarquia à república: momentos decisivos. São Paulo: Brasiliense, 1987.

FAORO, Raymundo. Os donos do poder. Porto Alegre: Globo, 1979. 2v.

FREIRE, Gilberto. Casa grande e senzala. São Paulo: Círculo do Livro, 1990.

ISAIA, Artur César. Catolicismo e autoritarismo no Rio Grande do Sul. Porto Alegre: EdPUCRS, 1998.

JARDIM, Antonio da Silva. Propaganda republicana (1888-1889). Rio de Janeiro: Casa de Rui Barbosa, 1978.

LARA, Tiago Adão. Tradicionalismo católico em Pernambuco. Recife: Fundarpe, 1988.

LEONARD, Emile-G. O protestantismo brasileiro. São Paulo: Aste/Juerp, 1981.

LIMA, Alceu Amoroso. Política. São Paulo: Herder, 1935.

MARTINS, Wilson. História da inteligência brasileira. São Paulo: TAO, 2001.

MATTOS, Ilmar Rohloff de. O tempo Saquarema. São Paulo: Hucitec; Brasília: INL, 1987.

MENDES, Fábio Faria. A economia moral do recrutamento militar no império brasileiro. Revista Brasileira de Ciências Sociais, Rio de Janeiro, v. 13, n. 38, 1998. Disponível em: <http://www.scielo.br/scielo.php?script=sci_arttext\&pid=S0102-69091998000300005>. Acesso em: 11 set. 2012.

MERCADANTE, Paulo. A consciência conservadora no Brasil. Rio de Janeiro: Saga, 1965.

OLIVEIRA, Bruno. Liberdade religiosa no Brasil império e no Brasil contemporâneo. Revista Eletrônica do Curso de Mestrado em Direito da UFAL, Maceió, v. 1, n. 1, jul./dez. 2010.

PAIM, Antonio. História das ideias filosóficas no Brasil. São Paulo: Convívio; Brasília: INL, 1984.

PEIXOTO, Antonio Carlos et. al. Liberalismo no Brasil Imperial. Origens, conceitos e prática. 2. ed. Rio de Janeiro: Revan, 2013.

PIÑEIRO, Théo Lobarinhas. Os projetos liberais no Brasil império. Passagens. Revista Internacional de História Política e Cultura Jurídica, Rio de Janeiro, v. 2, n. 4, p. 130-152, maio/ago. 2010.

RIBEIRO, Boanerges. Protestantismo no Brasil monárquico. 1822-1888. São Paulo: Perspectiva, 1973.

RIBEIRO, Gladys S. (Org.). Brasileiros e cidadãos: modernidade política, 1822-1930. São Paulo: Alameda, 2008.

ROCHA, João Gomes da. Lembranças do passado. Rio de Janeiro: CBP, 1941. 4v.

RODRIGUES, José Carlos. Religióes acatólicas. Memórias. Rio de Janeiro: Imprensa Nacional, 1903. 
SANTOS, João Marcos Leitão. Inflexôes em torno do pensamento jurídico de Antonio Coelho Rodrigues. Ariús, Campina Grande, v. 19, n. 2, p. 38-70, jul./dez. 2013. Disponível em: $<$ http://www.ch.ufcg.edu.br/arius/01_revistas/v19n2/arius_v19_n2_2013_sumario.htm>. SEIXAS, Romualdo de. Obras completas. Salvador: Lellis Masson, 1859. 6v.

SOUZA, François de Oliveira. Liberdade religiosa em um estado religioso: liberalismo e catolicismo nos debates da Assembleia Constituinte de 1823. Temporalidades, Belo Horizonte, v. 4, p. 229-249, ago./dez. 2012. Disponível em: <http://www.fafich.ufmg.br/ temporalidades/pdfs/07p229.pdf>. Acesso em: 20 dez. 2012.

VALLADÃO, Haroldo. História do direito principalmente brasileiro. Imperial e republicano. Rio de Janeiro: Freitas Bastos, 1973. 2v.

VEIGA, Gláucio. História das ideias da Faculdade de Direito do Recife. Recife: Edufpe, 1984/1990. t. IV, VII.

WOLKMER, Antonio Carlos. História do direito no Brasil. Rio de Janeiro: Forense, 1998.

\section{Como citar}

SANTOS, João Marcos Leitão dos. Ordem jurídica, religião, direitos civis e a constituição do Império do Brasil. Topoi. Revista de História, Rio de Janeiro, v. 19, n. 37, p. 6-32, jan./ abr. 2018. Disponível em: <www.revistatopoi.org>. 